\title{
Assessment of the antibacterial, cytotoxic and antioxidant activities of Morus nigra L. (Moraceae)
}

\author{
G. R. Souza ${ }^{a}$, R. G. Oliveira-Junior ${ }^{a}$, T. C. Diniz ${ }^{b}$, A. Branco ${ }^{b}$, S. R. G. Lima-Saraiva ${ }^{c}$, \\ A. L. Guimarães ${ }^{a}$, A. P. Oliveira ${ }^{a}$, A. G. M. Pacheco ${ }^{b}$, M. G. Silva ${ }^{a}$, M. O. Moraes-Filho, \\ M. P. Costa ${ }^{d}$, C. O. Pessoa ${ }^{d}$ and J. R. G. S. Almeida ${ }^{a *}$
}

${ }^{a}$ Núcleo de Estudos e Pesquisas de Plantas Medicinais, Universidade Federal do Vale do São Francisco - UNIVASF, Av. José de Sá Maniçoba, s/n, Bairro Centro, CEP 56304-205, Petrolina, PE, Brazil

bPrograma de Pós-graduação em Biotecnologia, Universidade Estadual de Feira de Santana - UEFS, Av. Transnordestina, s/n, Bairro Novo Horizonte, CEP 44036-900, Feira de Santana, BA, Brazil

'Programa de Pós-graduação em Ciências Farmacêuticas, Universidade Federal de Pernambuco - UFPE, Av. Prof. Moraes Rego, 1235, Bairro Cidade Universitária, CEP 50740-521, Recife, PE, Brazil

${ }^{\mathrm{d}}$ Faculdade de Medicina, Laboratório Nacional de Oncologia Experimental, Universidade Federal do Ceará - UFC, Rua Coronel Nunes de Melo, 1127, Bairro Rodolfo Teófilo, CEP 60020-181, Fortaleza, CE, Brazil

*e-mail: jackson.guedes@univasf.edu.br

Received: April 13, 2016 - Accepted: December 14, 2016 - Distributed: May 31, 2018

(With 1 figure)

\begin{abstract}
This study was carried out to assess the antibacterial, cytotoxic and antioxidant activities of extracts of Morus nigra L. HPLC was used to determine the fingerprint chromatogram of the crude ethanolic extract (Mn-EtOH). The antibacterial effect was assessed through the method of microdilution. The cytotoxicity was tested against human tumour cell lines using the 3-(4,5-dimethyl-2-thiazolyl)-2,5-diphenyl-2H-tetrazolium bromide (MTT) assay. The total phenolic and flavonoid contents were also assessed through the Folin-Ciocalteu and aluminum chloride methods, respectively. Antioxidant activities of the extracts were evaluated by using 2,2-diphenyl-1-picrylhydrazil (DPPH) radical scavenging and $\beta$-carotene-linoleic acid bleaching methods. The presence of phenolic compounds in $\mathrm{Mn}-\mathrm{EtOH}$ was confirmed using HPLC. The extracts showed activity against most microorganisms tested. The extracts did not show any expressive antiproliferative effect in the assessment of cytotoxicity. The most significant total phenolic content was $153.00 \pm 11.34 \mathrm{mg}$ of gallic acid equivalent/g to the ethyl acetate extract (AcOEt). The total flavonoid content was $292.50 \pm 70.34 \mathrm{mg}$ of catechin equivalent/g to the AcOEt extract, which presented the best antioxidant activity $\left(\mathrm{IC}_{50} 50.40 \pm 1.16 \mu \mathrm{g} / \mathrm{mL}\right)$ for DPPH scavenging. We can conclude that this species shows strong antibacterial and antioxidant activities, as well as weak cytotoxic effects.
\end{abstract}

Keywords: antibacterial, antioxidant, cytotoxic, Moraceae, Morus nigra.

\section{Avaliação das atividades antibacteriana, citotóxica e antioxidante de Morus nigra L. (Moraceae)}

\section{Resumo}

Este estudo foi realizado para avaliar as atividades antibacteriana, citotóxica e antioxidante de extratos de Morus nigra L. HPLC foi utilizado para determinar o perfil de compostos fenólicos do extrato etanólico bruto (Mn-EtOH). O efeito antibacteriano foi avaliado através do método de microdiluição. A citotoxicidade foi testada contra linhagens celulares de tumores humanos utilizando o ensaio do brometo de 3-(4,5-dimetil-2-tiazolil)-2,5-difenil-2H-tetrazólio (MTT). O conteúdo total de compostos fenólicos e flavonoides também foi avaliado por meio dos métodos de Folin-Ciocalteu e cloreto de alumínio, respectivamente. A atividade antioxidante dos extratos foi avaliada por meio do sequestro do radical livre 2,2-difenil-1-picrilhidrazil (DPPH) e co-oxidação do sistema $\beta$-caroteno-ácido linoleico. A presença de compostos fenólicos em Mn-EtOH foi confirmada utilizando HPLC. Os extratos mostraram atividade contra a maioria dos microrganismos testados. Os extratos não mostraram qualquer efeito antiproliferativo expressivo na avaliação da citotoxicidade. O conteúdo fenólico total mais significativo foi de 153,00 $\pm 11,34 \mathrm{mg}$ de equivalente de ácido gálico/g para o extrato acetato de etila (AcOEt). O conteúdo de flavonoides totais foi de 292,50 $\pm 70,34 \mathrm{mg}$ de equivalente de catequina/g para o extrato AcOEt, que apresentou a melhor atividade antioxidante $\left(\mathrm{IC}_{50} 50,40 \pm 1,16 \mathrm{mg} / \mathrm{mL}\right)$ para o sequestro do DPPH. Podemos concluir que esta espécie apresenta forte atividade antibacteriana e antioxidante, bem como fraca atividade citotóxica.

Palavras-chave: antibacteriana, antioxidante, citotóxica, Moraceae, Morus nigra. 


\section{Introduction}

Moraceae is a family of flowering plants that comprises about 40 genera and over 1,000 species (Pawlowska et al., 2008). The genus Morus is widely distributed in Asia, Europe, North America, South America and Africa, and is cultivated extensively in eastern, central, and southern Asia for silk production. Mulberry (Morus sp.) has been domesticated over thousands of years and has been adapted to a wide area of tropical, subtropical and temperate zones of the world (Ozgen et al., 2009).

Morus is a genus with species of deciduous trees. There are 24 species of Morus and one subspecies, with at least 100 known varieties (Padilha et al., 2010). Some species of this genus are widely cultivated in many countries, particularly in China and Japan, where mulberry is used for its foliage to feed the silkworm (Nomura, 1988). Species of this genus have also been used in folk medicine (especially in Chinese traditional medicine) as antiphlogistic, hepatoprotective, hypotensive, antipyretic, analgesic, diuretic, expectorant and antidiabetic (Nomura, 1988), as well as to treat anemia and arthritis (Ozgen et al., 2009). This genus contains a variety of phenolic compounds including flavonoids and stilbenes, as well as triterpenoids and alkaloids (Kumar and Chauhan, 2008).

Morus nigra, known as black mulberry, is one of the most important species of the genus Morus. It has juicy fruits with extraordinary color and a unique, slightly acidic flavor. The fruits are $2-3 \mathrm{~cm}$ long. Morus nigra has been used in folk medicine as an analgesic, diuretic, antitussive, sedative, anxiolytic and hypotensive, in addition to its uses in the treatment of a variety of ailments, including inflammatory disorders (Nomura and Hano, 1994).

There are few studies involving the chemical composition and assessment of the biological and pharmacological properties of Morus nigra collected in Brazil, mainly in the Northeast. In recent studies led by our research group, we assessed the hypoglycemic potential and acute toxicity of the crude ethanol extract from the leaves (Almeida et al., 2011), as well as the pre-clinical toxicological evaluation of the tea from the leaves (Oliveira et al., 2013) and the antinociceptive potential of this species (Souza et al., 2015). A review of medicinal plants and natural products from genus Morus with hypoglycaemic activity was also performed (Almeida et al., 2012). In this paper, we investigated the antibacterial, cytotoxic and antioxidant activities of extracts of leaves of $M$. nigra.

\section{Material and Methods}

\subsection{Plant material}

The leaves of Morus nigra L. (Moraceae) were collected in the Fazenda Ouro Verde, city of Casa Nova, State of Bahia, Brazil, in February 2010. A voucher specimen (1764) is deposited at the Herbarium Vale do São Francisco (HVASF) of the Federal University of San Francisco Valley.

\subsection{Extraction}

The dried and pulverized leaves (1196g) were macerated with ethanol $95 \%$ at room temperature for $72 \mathrm{~h}$. The solution was filtered and concentrated under reduced pressure in a rotatory evaporator at $50^{\circ} \mathrm{C}$, producing $64 \mathrm{~g}$ of crude ethanol extract (Mn-EtOH). The Mn-EtOH (60g) was suspended in a mixture of $\mathrm{H}_{2} \mathrm{O}: \mathrm{MeOH}(7: 3 \mathrm{v} / \mathrm{v})$ and extracted successively with hexane, chloroform $\left(\mathrm{CHCl}_{3}\right)$ and ethyl acetate (AcOEt) in crescent order of polarity to obtain the respective extracts: hexane $(9 g-14.97 \%)$, chloroform $(2.39 \mathrm{~g}-3.98 \%)$ and ethyl acetate $(1.90 \mathrm{~g}-3.16 \%)$.

\subsection{Analysis of Mn-EtOH through high-performance liquid chromatography (HPLC)}

The analysis of phenolic compound profile was performed in a Hitachi liquid chromatograph (Lachrom Elite model), LiCospher 100 RP18 column (5 mm) with dimensions $150 \mathrm{~mm} \times 04 \mathrm{~mm}$ (Merck), equipped with Diode Array Detector (DAD). The mobile phase used was a solution of $\mathrm{H}_{2} \mathrm{O} / \mathrm{H}_{3} \mathrm{PO}_{4} 0.1 \%$ (A) and $\mathrm{MeOH}(\mathrm{B})$ provided initial $75 \%$ of $A$ and $25 \%$ of $B$ for $25 \mathrm{~min}$. The column temperature was kept constant at $30{ }^{\circ} \mathrm{C}$ with a flow of $1.0 \mathrm{~mL} / \mathrm{min}$. For the extract, an injection volume of $20 \mu \mathrm{l}$ was used. Spectral data were recorded in $320 \mathrm{~nm}$ during the whole run.

\subsection{Microorganisms}

The reference bacterial strains used in this study were obtained from the National Institute of Quality Control in Health (INCQS/FIOCRUZ - Brazil). The microorganisms used were: Bacillus cereus (ATCC 11778), Enterococcus faecalis (ATCC 19433), Escherichia coli (ATCC 25922), Klebsiella pneumoniae (ATCC 13883), Salmonella choleraesuis (ATCC 10708), Serratia marcescens (ATCC 13880), Shigella flexneri (ATCC 12022) and Staphylococcus aureus (ATCC 25923).

\subsection{Determination of minimum inhibitory concentration (MIC) and minimum bactericidal concentration (MBC)}

The antibacterial effect was evaluated by means of the microdilution method as recommended by The National Committee for Clinical Laboratory Standards (Santos et al., 2012). Initially, a stock solution of $25 \mathrm{mg} / \mathrm{mL}$ of extracts was prepared using an aqueous solution of $20 \%$ DMSO (v/v). $200 \mu \mathrm{l}$ of this dilution was transferred to the microplate containing $200 \mu \mathrm{l}$ of Müller-Hinton broth. Afterwards, serial dilutions were performed resulting in concentrations of $25,12.5,6.25,3.12,1.56,0.78,0.39$ and $0.195 \mathrm{mg} / \mathrm{mL}$. The inoculum containing $5 \times 10^{5} \mathrm{CFU} / \mathrm{mL}(0.5$ in McFarland scale) was added to each well. Wells were reserved in the microplate for sterility control of the broth, the bacterial growth and the action of antimicrobial reference (Gentamicin). For gentamicin, an initial concentration of $1.6 \mathrm{mg} / \mathrm{mL}$ was used, which was diluted to concentrations of $0.8,0.4,0.2$, $0.1,0.05,0.025,0.0125 \mu \mathrm{g} / \mathrm{mL}$. The microplates were incubated under aerobic conditions for $18-24 \mathrm{~h}$ at $37^{\circ} \mathrm{C}$ when $10 \mu \mathrm{l}$ of 2,3,5-triphenyl-tetrazolium chloride (TTC) $2 \%$ was added to each well to detect the color change of 
the TTC (colorless) to red, reflecting the active bacterial metabolism.

The MIC was defined as the lowest concentration of the extracts that visibly inhibited the bacterial growth (showed by the lack of red color) (Scur et al., 2016). In order to determine the $\mathrm{MBC}$, aliquots of $10 \mu \mathrm{l}$ were withdrawn from each well containing the extracts and transferred to Petri dishes containing agar Müller-Hinton. The plates were incubated for $24 \mathrm{~h}$ at $37^{\circ} \mathrm{C}$. The appearance of bacterial colony for a given concentration indicates that it was not able to kill $99.9 \%$ or more bacterial inoculums used. Assays were performed in triplicate. The density of the extracts was employed to convert $\mu \mathrm{l} / \mathrm{mL}$ in $\mathrm{mg} / \mathrm{mL}$, the latter being used to express the $\mathrm{MIC}$ and $\mathrm{MBC}$.

\subsection{Cell line and cell culture}

Human tumour cell lines, including OVCAR-8 (ovarian), SF-295 (brain) and HCT-116 (colon) were obtained from the National Cancer Institute (Bethesda, MD, USA). All cells were maintained in RPMI 1640 medium supplemented with $10 \%$ fetal bovine serum, $100 \mathrm{U} / \mathrm{mL}$ penicillin and $100 \mu \mathrm{g} / \mathrm{mL}$ streptomycin at $37^{\circ} \mathrm{C}$ with $5 \% \mathrm{CO}_{2}$.

\subsection{Determination of cytotoxicity}

All extracts were tested for cytotoxic activity against three tumour cell lines. For all experiments, cells were placed in 96-well plates: OVCAR-8 $\left(0.1 \times 10^{6}\right.$ cells $\left./ \mathrm{mL}\right)$, SF-295 $\left(0.1 \times 10^{5}\right.$ cells $\left./ \mathrm{mL}\right)$ and HCT-116 $\left(0.7 \times 10^{6}\right.$ cells $\left./ \mathrm{mL}\right)$. After $24 \mathrm{~h}$, all extracts $(50 \mu \mathrm{g} / \mathrm{mL})$ dissolved in $1 \%$ DMSO were added to each well using a high-throughput screening system (Biomek 3000 - Beckman Coulter, Inc. Fullerton, CA, USA), and the cultures were incubated for $72 \mathrm{~h}$. Control groups received the same amount of DMSO.

The general viability of cultured cells was determined by the reduction of the yellow dye 3-(4,5-dimethyl-2thiazolyl)-2,5-diphenyl-2H-tetrazolium bromide (MTT) to a purple formazan product (CLSI, 2003). At the end of the incubation, the plates were centrifuged and the medium was replaced with fresh medium $(150 \mu \mathrm{l})$ containing MTT $(0.5 \mathrm{mg} / \mathrm{mL})$. Three hours later, the plates were centrifuged, the MTT formazan product was dissolved in $150 \mu 1 \mathrm{DMSO}$, and the absorbance was measured using a multi-plate reader (Spectra Count, Packard, Ontario, Canada). The extract effect was quantified as the percentage of the control absorbance of the reduced dye at $595 \mathrm{~nm}$. All absorbance values were converted into a cell growth inhibition percentage (GI\%) by the following formula: $\mathrm{GI} \%$ $=100-[(\mathrm{T} / \mathrm{C}) \times 100 \%]$, where $C$ was the absorbance for negative control and $T$ was the absorbance in the presence of the extracts tested. Each sample was tested in triplicate in two independent experiments.

\subsection{Total phenolic content}

Total phenolic contents were assayed using the FolinCiocalteu reagent, based on the method reported by (Slinkard and Singleton, 1977). An aliquot (40 $\mu$ l) of a suitably diluted $\mathrm{EtOH}$, hexane, $\mathrm{CHCl}_{3}$ and $\mathrm{AcOEt}$ extracts was added to $3.16 \mathrm{~mL}$ of distilled water and $200 \mu \mathrm{l}$ of the Folin-Ciocalteu reagent, and mixed thoroughly. The mixture was shaken and allowed to stand for $6 \mathrm{~min}$, before receiving the addition of $600 \mu \mathrm{l}$ of sodium carbonate solution, and shaken to properly mix. The solutions were left at $20^{\circ} \mathrm{C}$ for 2 hours and the absorbance of each solution was determined at $765 \mathrm{~nm}$ against the blank and plot absorbance vs. concentration. Total phenolic contents of the extracts (three replicates per treatment) were expressed as mg gallic acid equivalents per gram (mg GAE/g) through the calibration curve with gallic acid. The calibration curve range was $50-1000 \mathrm{mg} / 1$ $\left(\mathrm{R}^{2}=0.9938\right)$. All samples were performed in triplicate.

\subsection{Determination of total flavonoid content}

Total flavonoid content was determined by using a colorimetric method described previously (Zhishen et al., 1999). Briefly, $0.30 \mathrm{~mL}$ of the $\mathrm{EtOH}$, hexane, $\mathrm{CHCl}_{3}$ and AcOEt extracts, or $(+)$-catechin standard solution, was mixed with $1.50 \mathrm{~mL}$ of distilled water in a test tube followed by the addition of $90 \mu \mathrm{l}$ of a $5 \% \mathrm{NaNO}_{2}$ solution. After $6 \mathrm{~min}, 180 \mu \mathrm{l}$ of a $10 \% \mathrm{AlCl}_{3}$. $6 \mathrm{H}_{2} \mathrm{O}$ solution was added and allowed to stand for another $5 \mathrm{~min}$ before $0.6 \mathrm{~mL}$ of $1 \mathrm{M}$ $\mathrm{NaOH}$ was added. The mixture was brought to $330 \mu \mathrm{l}$ with distilled water and mixed thoroughly. The absorbance was measured immediately against the blank at $510 \mathrm{~nm}$ using a spectrophotometer (QUIMIS, Brazil) in comparison with the standards prepared similarly with known $(+)$-catechin concentrations. The results were expressed as $\mathrm{mg}$ of catechin equivalent to the gram of extracts $(\mathrm{mg} \mathrm{CE} / \mathrm{g})$ through the calibration curve with catechin $\left(\mathrm{R}^{2}=0.9948\right)$. The calibration curve range was $50-1000 \mathrm{mg} / \mathrm{l}$.

\subsection{DPPH free radical scavenging assay}

The free radical scavenging activity was measured using the 2,2-diphenyl-1-picrylhydrazil (DPPH) assay (Mensor et al., 2001). Sample stock solutions $(1.0 \mathrm{mg} / \mathrm{mL}$ ) of extracts were diluted to final concentrations of 243,81 , $27,9,3$ and $1 \mu \mathrm{g} / \mathrm{mL}$, in ethanol. One $\mathrm{mL}$ of a $50-\mu \mathrm{g} / \mathrm{mL}$ DPPH ethanol solution was added to $2.5 \mathrm{~mL}$ of sample solutions of different concentrations, and allowed to react at room temperature. After $30 \mathrm{~min}$, the absorbance values were measured at $518 \mathrm{~nm}$ and converted into the percentage antioxidant activity (AA) using the following formula: $\mathrm{AA} \%=[($ absorbance of the control - absorbance of the sample)/ absorbance of the control] $\times 100$.

Ethanol $(1.0 \mathrm{~mL})$ plus plant extract solutions $(2.5 \mathrm{~mL})$ were used as a blank. DPPH solution $(1.0 \mathrm{~mL})$ plus ethanol $(2.5 \mathrm{~mL})$ was used as a negative control. The positive controls (ascorbic acid, BHA and BHT) were those using the standard solutions. Assays were carried out in triplicate. The $\mathrm{IC}_{50}$ values were calculated through linear regression using by GraphPad Prism 5.0 program.

\subsection{1. $\beta$-Carotene bleaching test}

The $\beta$-carotene bleaching method is based on the loss of the yellow color of $\beta$-carotene due to its reaction with radicals formed by linoleic acid oxidation in an emulsion (Wannes et al., 2010). The rate of $\beta$-carotene bleaching can be slowed down in the presence of antioxidants. $\beta$-carotene $(2 \mathrm{mg}$ ) was dissolved in $10 \mathrm{~mL}$ chloroform and to $2 \mathrm{~mL}$ of this solution, linoleic acid $(40 \mathrm{mg})$ and Tween 
40 (400 mg) were added. Chloroform was evaporated under vacuum at $40^{\circ} \mathrm{C}$ and $100 \mathrm{~mL}$ of distilled water was added, then the emulsion was vigorously shaken during two minutes. Reference compounds (ascorbic acid, BHA and BHT) and sample extracts were prepared in ethanol. The emulsion $(3.0 \mathrm{~mL})$ was added to a tube containing $0.12 \mathrm{~mL}$ of solutions $1 \mathrm{mg} / \mathrm{mL}$ of reference compounds and sample extracts. The absorbance was immediately measured at $470 \mathrm{~nm}$ and the test emulsion was incubated in a water bath at $50{ }^{\circ} \mathrm{C}$ for $120 \mathrm{~min}$, when the absorbance was measured again.

Ascorbic acid, BHA and BHT were used as positive control. In the negative control, the extracts were replaced by an equal volume of ethanol. The antioxidant activity (\%) was assessed in terms of the bleaching of the $\beta$-carotene using the following formula: \% Antioxidant activity $=\left[1-\left(\mathrm{A}_{0}-\mathrm{A}\right) /\left(\mathrm{A}_{0}{ }^{0}-\mathrm{A}_{\mathrm{t}}{ }^{0}\right)\right] \times 100$, where $\mathrm{A}_{0}$ is the initial absorbance and $A_{t}$ is the final absorbance measured for the test sample, $\mathrm{A}_{0}{ }^{0}$ is the initial absorbance and $\mathrm{A}_{\mathrm{t}}^{0}$ is the final absorbance measured for the negative control (blank).

The results are expressed as percentage of antioxidant activity ( $\%$ AA). Tests were carried out in triplicate. The data obtained were analyzed using the GraphPad Prism ${ }^{\circledR}$ version 5.0 and expressed as mean \pm S.D. Statistically significant differences between groups were calculated by the application of Student's $t$-test. Values were considered significantly different from $\mathrm{p}<0.05$.

\section{Results and Discussion}

High-performance liquid chromatography with diode array detection (HPLC-DAD) accounts for a crucial, reliable technique for the characterization of phenolic compounds due to its versatility, precision and relatively low cost. Preliminary phytochemical analysis demonstrated that Mn-EtOH contains phenols, flavonoids, steroids and terpenoides (data not shown). Phenolic profile at $320 \mathrm{~nm}$ for the $\mathrm{Mn}-\mathrm{EtOH}$ evaluated is presented in Figure 1. The chromatogram shows the presence of four peaks with

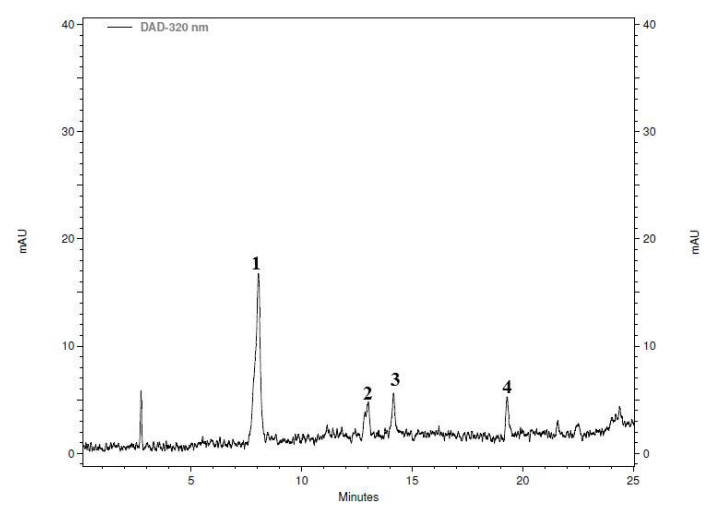

Figure 1. High-performance liquid chromatography with diode array detector (HPLC-DAD) profiles of Morus nigra ethanolic extract recorded at $320 \mathrm{~nm}$. retention times between 5 and $20 \mathrm{~min}$. Based on their UV-Vis spectral data and their retention time, the compounds have UV bands characteristic of phenolic compounds, possibly flavonoid and phenolic acids (peak 1: $\lambda_{\text {max. }} 240$ and $330 \mathrm{~nm}$ - flavonoid; peaks 2, 3 and 4: $\lambda_{\text {max. }} 230 \mathrm{~nm}$, phenolic acids). These compounds are being currently investigated.

The abusive and indiscriminate use of antimicrobial compounds over many years is the main factor responsible for the appearance of the phenomenon of bacterial resistance to such compounds. Several alternatives have been suggested to solve this problem, such as the search for new antimicrobials in plant species. Some plants synthetize substances with antimicrobial properties such as terpenoids, phenolics (especially flavonoids) and nitrogen compounds (Politi et al., 2011). The results from the evaluation of the antibacterial activity for extracts of M. nigra are shown in Table 1, and are expressed as minimum inhibitory concentration (MIC) and minimum bactericidal concentration (MBC).

The antibacterial activity was assessed against eight reference bacteria. The extracts showed activity against most of the microorganisms tested. The crude ethanol extract $(\mathrm{Mn}-\mathrm{EtOH})$ showed bactericidal activity against Gram-positive strains B. cereus and E. faecalis as well as against Gram-negative $E$. coli strain (Table 1). The hexane extract was also effective against the growth of $B$. cereus and $E$. faecalis. Furthermore, it could inhibit the growth of E. coli, S. choleraesuis and $S$. marcescens at a concentration of $3.12 \mathrm{mg} / \mathrm{mL}$ (Table 1).

An interesting result was observed for the chloroform extract, which presented bactericidal activity against strains of $S$. choleraesuis in the lowest concentration used during the experiment (Table 1). The ethyl acetate extract is composed predominantly of polar compounds such as phenolic substances. Many studies have shown that these classes of secondary metabolites exhibit antibacterial activity and are, probably, responsible for the results obtained using this extract.

In a review published on the antimicrobial activity of flavonoids, Cushnie and Lamb (2005) reported that many research groups have isolated and identified the structure of flavonoids that exerts antibacterial activity. Examples of such flavonoids are apigenin, galangin, pinocembrin, ponciretin, genkwanin, sophoraflavanone $G$ and their derivatives. Other flavones, flavone glycosides, isoflavones, flavanones, isoflavanones, isoflavans, flavonols, flavonol glycosides and chalcones with antibacterial activity have also been identified (Cushnie and Lamb, 2005). It is possible for substances present in the extracts to exert antimicrobial activity. The exact mechanism and the bioactive principles responsible for such effect are still to be explained. Thus, it would be very interesting to fractionate the extracts, isolate the compounds and obtain a more accurate assessment.

The cytotoxicity of the extracts was tested against OVCAR-8 (ovarian), SF-295 (brain) and HCT-116 (colon) human tumour cell lines using the thiazolyl-blue test (MTT) assay. MTT assay is a well-characterized colorimetric assay based on the enzymatic reduction of 
Table 1. Antibacterial activity of ethanolic $(\mathrm{EtOH})$, hexane, chloroform $\left(\mathrm{CHCl}_{3}\right)$ and ethyl acetate $(\mathrm{AcOEt})$ extracts from the leaves of Morus nigra.

\begin{tabular}{|c|c|c|c|c|c|c|c|c|}
\hline \multicolumn{9}{|c|}{ Antibacterial activity of Morus nigra extracts } \\
\hline \multirow{2}{*}{ Microorganisms } & \multicolumn{4}{|c|}{ MIC $(\mathrm{mg} / \mathrm{mL})$} & \multicolumn{4}{|c|}{ MBC (mg/mL) } \\
\hline & EtOH & Hexane & $\mathrm{CHCl}_{3}$ & AcOEt & EtOH & Hexane & $\mathrm{CHCl}_{3}$ & AcOEt \\
\hline Bacillus cereus & $<0.195$ & $<0.195$ & $<0.195$ & $<0.195$ & $<0.195$ & 12.50 & 6.25 & 6.25 \\
\hline Enterococcus faecalis & $<0.195$ & $<0.195$ & $<0.195$ & $<0.195$ & $<0.195$ & 12.50 & 6.25 & 6.25 \\
\hline Escherichia coli & $<0.195$ & 3.12 & 1.56 & 0.78 & $<0.195$ & 6.25 & 12.50 & 6.25 \\
\hline Klebsiella pneumoniae & 0.390 & 6.25 & 3.12 & 6.25 & - & 25 & 6.25 & 25 \\
\hline Salmonella choleraesuis & 12.50 & 3.12 & $<0.195$ & 3.12 & - & 25 & $<0.195$ & 3.12 \\
\hline Serratia marcescens & 12.50 & 3.12 & 1.56 & 3.12 & - & 12.50 & 12.50 & 3.12 \\
\hline Shigela flexneri & 12.50 & 6.25 & 3.12 & 0.78 & - & 6.25 & 6.25 & 6.25 \\
\hline Staphylococcus aureus & 12.50 & 6.25 & 6.25 & 6.25 & - & 6.25 & 6.25 & 6.25 \\
\hline
\end{tabular}

MIC: minimal inhibitory concentration; MBC: minimum bactericidal concentration; (-) Microbial growth at all tested concentrations.

Table 2. Cell proliferation inhibition (\%) of extracts of Morus nigra determined by MTT assay after $72 \mathrm{~h}$ of incubation at the concentration of $50 \mu \mathrm{g} / \mathrm{mL}$.

\begin{tabular}{cccc}
\hline \multirow{2}{*}{ Extracts } & \multicolumn{3}{c}{ Cell proliferation inhibition (\%) } \\
\cline { 2 - 4 } & OVCAR-8 & SF-295 & HCT-116 \\
\hline Mn-EtOH & 47.67 & 38.44 & 34.78 \\
Hexane & 41.69 & 70.48 & 50.85 \\
$\mathrm{CHCl}_{3}$ & 39.08 & 49.72 & 56.56 \\
$\mathrm{AcOEt}$ & -8.45 & -5.30 & -0.79 \\
\hline
\end{tabular}

Table 3. Total phenolics (TP), total flavonoids (TF) and antioxidant activity of extracts from the leaves of Morus nigra L.

\begin{tabular}{|c|c|c|c|c|}
\hline Extract & TP (mg GAE/g) & TF (mg CE/g) & $\begin{array}{c}\text { DPPH } \\
\left(\mathrm{IC}_{50}, \mu \mathrm{g} / \mathrm{mL}\right)\end{array}$ & $\begin{array}{c}\beta \text {-carotene } \\
(\% \text { AA) }\end{array}$ \\
\hline Mn-EtOH & $58.05 \pm 5.20$ & $35.48 \pm 6.86$ & $69.10 \pm 1.88$ & $41.30 \pm 12.80$ \\
\hline Hexane & $41.38 \pm 0.00$ & ---- & $>243$ & $51.36 \pm 4.88$ \\
\hline $\mathrm{CHCl}_{3}$ & $51.38 \pm 7.50$ & ---- & $>243$ & $47.95 \pm 17.06$ \\
\hline AcOEt & $153.00 \pm 11.34$ & $292.50 \pm 70.34$ & $50.40 \pm 1.16$ & $54.10 \pm 12.34$ \\
\hline Ascorbic acid & ---- & --- & $5.68 \pm 0.03$ & $0.79 \pm 2.21$ \\
\hline BHA & ---- & ---- & $1.67 \pm 0.30$ & $80.93 \pm 3.45$ \\
\hline BHT & ---- & ---- & $0.65 \pm 0.13$ & $86.77 \pm 1.14$ \\
\hline
\end{tabular}

the tetrazolium salt MTT in living, metabolically active cells, but not in dead cells. It has been largely used to determine the cytostatic/cytotoxic potential of medicinal agents in screening programs (Santos-Júnior et al., 2010). The cytotoxicity of the extracts was initially tested against tumour cell lines using the thiazolyl-blue test (MTT) assay at a concentration of $50 \mu \mathrm{g} / \mathrm{mL}$ (Table 2). Those extracts that caused more than $75 \%$ cell growth inhibition in any cell line were considered active. Our results demonstrated that none of the extracts tested obtained from leaves of M. nigra were shown to be cytotoxic. They did not show any expressive antiproliferative effect. Thus, we can conclude that this species presents weak cytotoxic effects in the conditions tested.

Table 3 summarizes the results from the quantitative determination of phenolic and flavonoids as well as the effect of extracts from $M$. nigra, ascorbic acid, BHA and $\mathrm{BHT}$ on the DPPH free radical scavenging and $\beta$-carotenelinoleic acid bleaching test. Considering that the aim of this study was to evaluate the antibacterial and antioxidant effects of the extracts and given the antibacterial and antioxidant activity described for the flavonoids, it was important to estimate the contents of total phenolic and flavonoids in the extracts.

The total phenolic contents of the extracts were determined by means of the Folin-Ciocalteu method as gallic acid equivalent in milligrams to each gram (mg GAE/g), while total flavonoid contents were calculated as catechin equivalent in milligrams to each gram ( $\mathrm{mg} \mathrm{CE} / \mathrm{g})$. Among the four extracts, ethyl acetate extract (AcOEt) contained the highest $(153.00 \pm 11.34)$ amount of phenolic compounds followed by the crude ethanol extract $(58.05 \pm 5.20)$. For the total flavonoid content, the highest value was observed in AcOEt extract $(292.50 \pm 70.34)$ while the crude ethanol extract $(\mathrm{Mn}-\mathrm{EtOH})$ presented $35.48 \pm 6.86 \mathrm{mg} \mathrm{CE} / \mathrm{g}$. The total flavonoid content of the hexane and chloroform $\left(\mathrm{CHCl}_{3}\right)$ extracts were note determined.

In the present study, the antioxidant ability of the M. nigra extracts was investigated through some in vitro models such as radical scavenging activity using, 2,2-diphenyl-1- 
picrylhydrazyl (DPPH) method and $\beta$-carotene-linoleate model system. Antioxidant activity on method of DPPH was expressed as $\mathrm{IC}_{50}$ which is defined as the sufficient concentration to obtain $50 \%$ of a maximum effect estimate in $100 \%$. Lower $\mathrm{IC}_{50}$ value indicated higher antioxidant activity. In $\beta$-carotene-linoleate model system, the antioxidant activity was expressed as percentage of antioxidant activity (\%AA). DPPH is a stable free radical interacting with antioxidant substances, which transfer electrons or atoms of hydrogen to DPPH, neutralizing ("scavenging") the free radical. This process can be observed as a change in the color of the reaction agent from violet to yellow and a reduction in the absorbance at $517 \mathrm{~nm}$ (Benites et al., 2015; Banerjee et al., 2005). The data showed that the EtOH and AcOEt extracts exhibited excellent free radical scavenging activity $\left(\mathrm{IC}_{50}<100 \mu \mathrm{g} / \mathrm{mL}\right)$. The AcOEt extract showed better antioxidant with a value of $\mathrm{IC}_{50}$ of $50.40 \pm 1.16 \mu \mathrm{g} / \mathrm{mL}$. BHT was the most effective antioxidant, with a value of $\mathrm{IC}_{50}$ of $0.65 \pm 0.13 \mu \mathrm{g} / \mathrm{mL}$. The presence of phenolic compounds in the extracts was shown to be essential for scavenger properties. The antioxidant activity of extracts was also assessed with the $\beta$-carotene/linoleate bleaching method. The addition of extracts, ascorbic acid, BHA and BHT prevented the bleaching of $\beta$-carotene to different degrees. All extracts had lower antioxidant activity than did BHT and BHA.

The results presented in this paper showed that M. nigra has a substantial amount of phenolics that could be responsible for its marked antibacterial and antioxidant activities. The absence of cytotoxicity and high antibacterial and antioxidant activities were the main findings of this work. Further studies are encouraged in the search for bioactive molecules from this plant.

\section{Acknowledgements}

This work was supported by grants from Brazilian agencies CNPq, FACEPE and FUNCAP. We also would like to thank teacher Abilio Borghi for the grammar review of the manuscript.

\section{References}

ALMEIDA, J.R.G.S., GUIMARÃES, A.L., OLIVEIRA, A.P., ARAÚJO, E.C.C., SILVA, F.S., NEVES, L.F., OLIVEIRA, R.A., SÁ, P.G.S. and QUINTANS-JÚNIOR, L.J., 2011. Evaluation of hypoglycemic potential and pre-clinical toxicology of Morus nigra L. (Moraceae). Latin American Journal of Pharmacy, vol. 30, pp. 96-100.

ALMEIDA, J.R.G.S., SOUZA, G.R., ARAÚJO, E.C.C., SILVA, F.S., LIMA, J.T., RIBEIRO, L.A.A., NUNES, X.P., BARBOSAFILHO, J.M., QUINTANS-JUNIOR, L.J. and SANTOS, M.R.V., 2012. Medicinal plants and natural compounds from the genus Morus (Moraceae) with hypoglycemic activity: a review. Rijeka: InTech, pp. 189-206.

BANERJEE, A., DASGUPTA, N. and DE, B., 2005. In vitro study of antioxidant activity of Syzygium cumini fruit. Food Chemistry, vol. 90, no. 4, pp. 727-733. http://dx.doi.org/10.1016/j. foodchem.2004.04.033.
BENITES, R.S.R., FORMAGIO, A.S.N., ARGANDOÑA, E.J.S., VOLOBUFF, C.R.F., TREVIZAN, L.N.F., VIEIRA, M.C. and SILVA, M.S., 2015. Contents of constituents and antioxidant activity of seed and pulp extracts of Annona coriacea and Annona sylvatica. Brazilian Journal of Biology = Revista Brasileira de Biologia, vol. 75, no. 3, pp. 685-691. PMid:26421762. http:// dx.doi.org/10.1590/1519-6984.21313.

CLINICAL LABORATORY STANDARDS INSTITUTE CLSI, 2003. Metodologia dos testes de sensibilidade a agentes antimicrobianos por diluição para bactérias de crescimento aeróbico: norma aprovada. 6th ed. vol. 23, pp. M7-A6.

CUSHNIE, T.P.T. and LAMB, A.J., 2005. Antimicrobial activity of flavonoids. International Journal of Antimicrobial Agents, vol. 26, no. 5, pp. 343-356. PMid:16323269. http://dx.doi.org/10.1016/j. ijantimicag.2005.09.002.

KUMAR, V.R. and CHAUHAN, S., 2008. Mulberry: Life enhancer. Journal of Medicinal Plants Research, vol. 2, pp. 271-278.

MENSOR, L.L., MENEZES, F.S., LEITÃO, G.G., REI, S.A.S., SANTOS, T.C., COUBE, C.S. and LEITÃO, S.G., 2001. Screening of Brazilian plant extracts for antioxidant activity by the use of DPPH free radical method. Phytotherapy Research, vol. 15 , pp. 127-130.

NOMURA, T. and HANO, Y., 1994. Isoprenoid-substituted phenolic compounds of moraceous plants. Natural Product Reports, vol. 11, no. 2, pp. 205-218. PMid:15209130. http:// dx.doi.org/10.1039/np9941100205.

NOMURA, T., 1988. Phenolic compounds of the mulberry tree and related plants. Progress in the Chemistry of Organic Natural Products, vol. 53, pp. 87-201. PMid:3069663.

OLIVEIRA, A.C.B., OLIVEIRA, A.P., GUIMARÃES, A.L., OLIVEIRA, R.A., SILVA, F.S., REIS, S.A.G.B., RIBEIRO, L.A.A. and ALMEIDA, J.R.G.S., 2013. Avaliação toxicológica pré-clínica do chá das folhas de Morus nigra L. (Moraceae). Revista Brasileira Plantas Medicinais, vol. 15, no. 2, pp. 244-249. http:// dx.doi.org/10.1590/S1516-05722013000200012.

OZGEN, M., SERÇE, S. and KAYA, C., 2009. Phytochemical and antioxidant properties of anthocyanin-rich Morus nigra and Morus rubra fruits. Scientia Horticulturae, vol. 119, no. 3, pp. 275-279. http://dx.doi.org/10.1016/j.scienta.2008.08.007.

PADILHA, M.M., MOREIRA, L.Q., MORAIS, F.F., ARAÚJO, T.H. and SILVA, G.A., 2010. Estudo farmacobotânico das folhas de amoreira-preta, Morus nigra L., Moraceae. Brazilian Journal Pharmacognosy, vol. 20, pp. 621-626. http://dx.doi.org/10.1590/ S0102-695X2010000400024.

PAWLOWSKA, A.M., OLESZEK, W. and BRACA, A., 2008. Quali-quantitative analyses of flavonoids of Morus nigra L. and Morus alba L. (Moraceae) fruits. Journal of Agricultural and Food Chemistry, vol. 56, no. 9, pp. 3377-3380. PMid:18412362. http://dx.doi.org/10.1021/jf703709r.

POLITI, F.A.S., MELLO, J.C.P., MIGLIATO, K.F., NEPOMUCENO, A.L.A., MOREIRA, R.R.D. and PIETRO, R.C.L.R., 2011. Antimicrobial, cytotoxic and antioxidant activities and determination of the total tannin content of bark extracts Endopleura uchi. International Journal of Molecular Sciences, vol. 12, no. 4, pp. 2757-2768. PMid:21731469. http://dx.doi.org/10.3390/ ijms 12042757 .

SANTOS, T.G., REBELO, R.A., DALMARCO, E.M., GUEDES, A., GASPER, A.L., CRUZ, A.B., SCHMIT, A.P., CRUZ, R.C.B., STEINDEL, M. and NUNES, R.K., 2012. Composição química e 
avaliação da atividade antimicrobiana do óleo essencial das folhas de Piper malacophyllum (C. Presl.) C. DC. Química Nova, vol. 35 , no. 3, pp. 477-481.

SANTOS-JÚNIOR, H.M., OLIVEIRA, D.F., CARVALHO, D.A., PINTO, J.M.A., CAMPOS, V.A.C., MOURÃO, A.R.B., PESSOA, C., MORAES, M.O. and COSTA-LOTUFO, L.V., 2010. Evaluation of native and exotic Brazilian plants for anticancer activity. Journal of Natural Medicines, vol. 64, no. 2, pp. 231-238. PMid:20127421. http://dx.doi.org/10.1007/s11418-010-0390-0.

SCUR, M.C., PINTO, F.G.S., PANDINI, J.A., COSTA, W.F., LEITE, C.W. and TEMPONI, L.G., 2016. Antimicrobial and antioxidant activity of essential oil and diferente plant extracts of Psidium cattleianum Sabine. Brazilian Journal of Biology = Revista Brasileira de Biologia, vol. 76, no. 1, pp. 101-108. PMid:26871744. http://dx.doi.org/10.1590/1519-6984.13714.

SLINKARD, K. and SINGLETON, V.L., 1977. Total phenol analysis: automation and comparison with manual methods. American Journal of Enology and Viticulture, vol. 28, pp. 49-55.
SOUZA, G.R., SILVA, J.C., OLIVEIRA-JUNIOR, R.G., LIMASARAIVA, S.R.G., GUIMARAES, A.L., OLIVEIRA, A.P. and ALMEIDA, J.R.G.S., 2015. Atividade antinociceptiva do extrato etanólico das folhas de Morus nigra L. (Moraceae). Revista de Ciências Farmacêuticas Básica e Aplicada, vol. 36, pp. 137-142.

WANNES, W.A., MHAMDI, B., SRITI, J., JEMIA, M.B., OUCHIKH, O., HAMDAOUI, G., KCHOUK, M.E. and MARZOUK, B., 2010. Antioxidant activities of the essential oil and methanol extracts from myrtle (Myrtus communis var. italica L.) leaf, stem and flower. Food and Chemical Toxicology, vol. 48, no. 5, pp. 1362-1370. PMid:20211674. http://dx.doi. org/10.1016/j.fct.2010.03.002.

ZHISHEN, J., MENGCHENG, T. and JIANMING, W., 1999. The determination of flavonoid contents in mulberry and their scavenging effects on superoxide radicals. Food Chemistry, vol. 64, no. 4, pp. 555-559. http://dx.doi.org/10.1016/S03088146(98)00102-2. 